\title{
Mutagenesis of a Rhizobium Plasmid Carrying Hydrogenase Determinants
}

\author{
By S. A. KAGAN AND N. J. BREWIN* \\ John Innes Institute, Colney Lane, Norwich NR4 7UH, UK
}

(Received 16 July 1984; revised 6 December 1984)

\begin{abstract}
Transposon Tn5-mob, a Tn5 derivative containing the mobilization site of plasmid RP4, was introduced into Rhizobium leguminosarum strain $128 \mathrm{C} 53$ on the suicide vector pSup5011. Transposon insertions into the plasmids of strain $128 \mathrm{C} 53$ were selected after mating the mutagenized population with a non-nodulating $R$. leguminosarum recipient. In this way, a tenfold enrichment was effected for plasmid-linked mutations. Transconjugants that had received mutagenized symbiotic plasmids were applied individually to the roots of pea seedlings and, after three weeks, the resulting nodules were screened for the absence of hydrogenase activity. Eight hydrogenase-deficient $\left(\mathrm{Hup}^{-}\right)$mutants of $R$. leguminosarum strain $128 \mathrm{C} 53$ were isolated. Physical and genetic analyses suggest that each Hup mutant was due to a single insertion of Tn5-mob into the symbiotic plasmid, pRL6JI. All mutations were suppressible by pHU1, a cosmid clone carrying some of the hup genes of Rhizobium japonicum.
\end{abstract}

\section{INTRODUCTION}

Uptake hydrogenase systems have been found in many nitrogen-fixing bacteria, both freeliving and symbiotic. Many possible beneficial roles have been suggested for these enzymes (for a review see Eisbrenner \& Evans, 1983) yet they are not essential for bacterial growth under most conditions. In order to assess the role of hydrogenase in the Rhizobium/plant symbiosis, mutants must be isolated and their effects on the symbiosis determined. In $R$. japonicum, hydrogenase mutants have been isolated by screening bacteria on agar for the inability either to reduce the dye methylene blue (Lepo et al., 1981) or to grow chemolithotrophically (Maier, 1981), both of which activities require hydrogenase. In $R$. leguminosarum, such screening of bacteria is not possible since the hydrogenase appears to be expressed only in the nodule and not in the free-living state. Therefore, screening for hydrogenase mutants must be done on plants, where the bacteria differentiate to the nitrogen-fixing bacteroid forms.

The $R$. leguminosarum commercial inoculant strain 128C53 (Nitragin) has been shown to contain a plasmid, pRL6JI, which determines hydrogenase activity (Brewin et al., 1980). This plasmid also determines nodulation, host range, and nitrogen fixation functions. However, pRL6JI is not self-transmissible, nor can it be mobilized efficiently by other plasmids. If it were transmissible, an enrichment procedure subsequent to a transposon mutagenesis (as described by Buchanan-Wollaston et al., 1980) could be employed to obtain mutagenized plasmids. As an alternative, the following mutagenesis scheme was devised to generate mutants of $R$. leguminosarum strain 128C53 that were deficient in hydrogenase. The procedure involves the introduction of ' $\mathrm{Tn} 5$-mob', a Tn 5 derivative which carries the mobilization site of plasmid RP4 in the central, unique region of the transposon (Simon et al., 1983). Simon et al. (1983) used this transposon to mobilize the megaplasmid of $R$. meliloti into Agrobacterium tumefaciens. When Tn5-mob inserts into a plasmid, it simultaneously renders that plasmid mobilizable by RP4, causes an insertion mutation, and confers kanamycin resistance on the host cell. Thus, by selecting for mobilizable kanamycin resistance in the mutagenized population, insertions in the plasmids are enriched preferentially to those in the chromosome, since mobilization of plasmids is much more efficient than that of the chromosome. This method has general applicability in the isolation of mutants of any non-transmissible, plasmid-borne gene. 
Table 1. Bacterial strains, phage and plasmids

Relevant characteristics*

Reference

Rhizobium leguminosarum

$128 \mathrm{C} 53$

3855

6015

B 157

3688

Rhizohium phage

RL.38J]

Escherichia coli strains

S17-1

Plasmids

pJB3JI

$\mathrm{pHUI}$

pRK2013

pSup5011

pRL6JI

pRLI3JI
$\mathrm{Nod}^{+} \mathrm{Fix}^{+} \mathrm{Hup}^{+} \mathrm{Rhi}^{+}$prototrophic

128C 53 str-279

nod-6007 $\mathrm{Rhi}^{-}$trp-12 phe-I rif-392 str-32

$3855 \wedge(\mathrm{pRL6JI})$ rif-399

6015/pRLIJI Nod ${ }^{+} \mathrm{Fix}^{+} \mathrm{Hup}^{-}$

chr::RP4-2 (Tet::Mu) (Kan::Tn7) Pro-

Tetr Ampr (R68.45. Kan $\left.{ }^{\mathrm{s}}\right)$

Tet $^{r}$

Mobilizes Tn5-mob

pBR325::Tn5-mob

Symbiotic plasmid (190 MDal) from $3855 \mathrm{Nod}^{+}$

$\mathrm{Fix}^{+} \mathrm{Hup}^{+} \mathrm{Rhi}^{+}$

Cryptic plasmid (250 MDal) from 3855
Brewin et al. (1982)

Brewin et al. (1982)

Johnston et al. (1978)

Brewin et al. (1982)

Downie et al. (1983)

Buchanan-Wollaston (1979)

Simon et al. (1983)

Brewin et al. (1982)

Cantrell et al. (1983)

Ditta et al. (1980)

Simon et al. (1983)

Brewin et al. (1982)

Brewin et al. (1982)

* Nod, nodulation genes; Fix, nitrogen fixation genes; Hup, uptake hydrogenase genes; Rhi, 24 kDal rhizosphere protein genes.

\section{METHODS}

Bacterial strains, phage and plasmids are listed in Table 1. Media and general growth conditions were as described by Beringer (1974). Patch crosses were performed as described by Buchanan-Wollaston et al. (1980) and filter crosses as described by Beringer et al. (1978). Peas (cv. Wisconsin Perfection) were surface sterilized, inoculated and grown according to Beynon at al. (1980).

Antibiotics were obtained from Sigma and used at the following concentrations: kanamycin, $60 \mu \mathrm{g} \mathrm{ml}^{-1}$; streptomycin, $200 \mu \mathrm{g} \mathrm{ml}^{-1}$; tetracycline, $5 \mu \mathrm{g} \mathrm{ml}^{-1}$; rifampicin, $20 \mu \mathrm{g} \mathrm{ml}^{-1}$.

Bacteriophage lysates were prepared as described by Buchanan-Wollaston (1979). They were treated with UV light to attenuate the phages, and then used in transductions.

Plasmid DNA from R. leguminosarum was prepared and subjected to electrophoresis by the method of Hirsch $e t$ al. (1980).

Immunochemical screening was performed on Rhizobium colonies that were blotted onto nitrocellulose, lysed in situ, and probed with an antibody to a rhizosphere protein (Dibb et al., 1984). Cross-reacting material was detected by a second antibody that was conjugated to horse-radish peroxidase.

Hydrogenase activity was detected by whole nodule incorporation of tritiated hydrogen as described by Brewin et al. (1982).

\section{RESULTS}

\section{Introduction of Tn5-mob into R. leguminosarum}

In order to see whether Tn5-mob could be transferred into $R$. leguminosarum, and if so, whether it would cause the plasmids to be more highly mobilizable than the chromosome, we made the following bacterial matings. Rhizobium strain 3855 (a streptomycin-resistant derivative of $128 \mathrm{C} 53$ ) was mated on filters with $E$. coli strain S17-1 containing plasmid pSup5011 for $5 \mathrm{~h}$ at $28^{\circ} \mathrm{C}$. The plasmid pSup5011 carries Tn5-mob, and cannot replicate in Rhizobium. Transconjugants which had received Tn5-mob were selected on the basis of kanamycin resistance; they occurred at a frequency of $10^{-5}$ per recipient. Two hundred and fifty individual kanamycin-resistant transconjugants resulting from the conjugation of strains S17-1/pSup5011 and 3855 were assayed for their ability to have their kanamycin resistance mobilized by a kanamycin-sensitive derivative of RP4, pJB3JI, in patch crosses. This was done by first introducing pJB3JI into the strains by conjugation from $E$. coli. Subsequently these transconjugant strains were used as donors in conjugations with a $\mathrm{Nod}^{-}$Rhizobium recipient (B157 or 6015); kanamycin-resistant transconjugants were scored. Only $24(9.6 \%)$ of the donors containing Tn5-mob were mobilizable. Presumably, the other 226 donor strains had insertions 


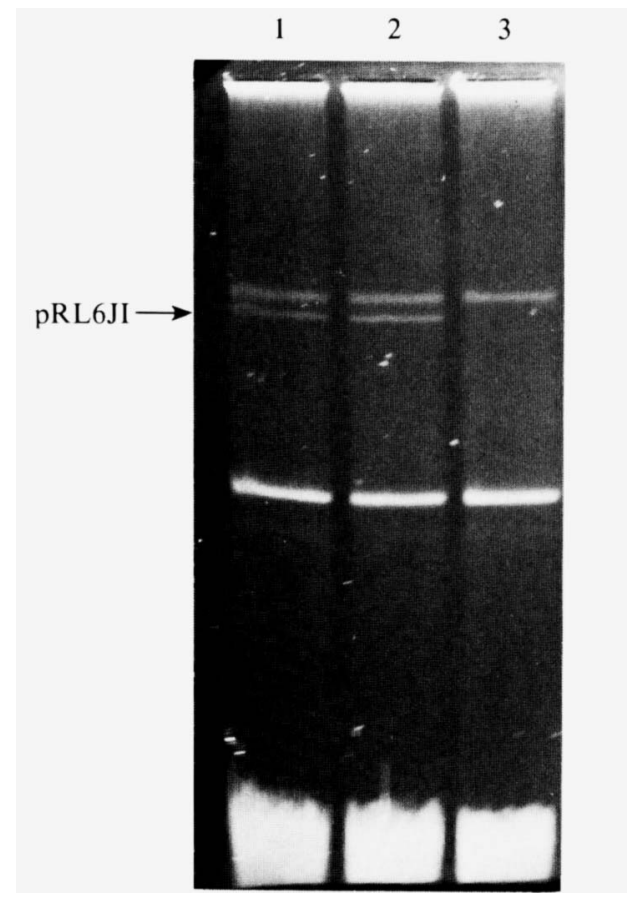

Fig. 1. Mobilization of pRL6JI by virtue of Tn5-mob insertion. Lane I, strain 3855/pJB3JI; lane 2, transconjugant of $3855:: \mathrm{Tn} 5-\mathrm{mob} / \mathrm{pJB} 3 \mathrm{JI} \times \mathrm{B} 157$ which makes $24 \mathrm{kDal}$ rhizosphere protein; lane 3 , transconjugant of $3855:: \mathrm{Tn} 5-\mathrm{mob} / \mathrm{pJB} 3 \mathrm{JI} \times \mathrm{B} 157$ which does not make $24 \mathrm{kDal}$ rhizosphere protein.

of Tn5-mob in the chromosome and hence were mobilizable at a much lower frequency, undetectable in patch crosses. This showed that $\mathrm{Tn} 5$-mob functioned in $R$. leguminosarum, and suggested that enrichment for plasmid mutations was possible.

\section{Enrichment by conjugation}

About 300000 colonies of strain 3855 which had received Tn 5 -mob were pooled. Plasmid pJB3JI was introduced as a mobilizing plasmid into this population, in a filter cross from $E$. coli, selecting for the acquisition of tetracycline resistance. Approximately 100000 different such strains (3855::Tn5-mob/pJB3JI) were pooled, grown up and used as donors in filter crosses with two different rifampicin-resistant, nodulation-deficient strains, B157 and 6015. Rifampicinresistant, kanamycin-resistant colonies appeared at a frequency of $10^{-5}-10^{-6}$ per recipient. These transconjugants were presumed to have a plasmid-borne insertion of $\mathrm{Tn} 5$-mob, and in all cases examined pJB3JI had been cotransferred.

\section{Immunochemical screening}

Since strain 3855 has at least two plasmids, pRL6JI and pRL13JI, an attempt was made to identify those in which Tn5-mob was carried on plasmid pRL6JI. This was done by using an immunochemical procedure which recognizes a $24 \mathrm{kDal}$ protein known to be coded by pRL6JI, and expressed in the free-living state (Dibb et al., 1984). The recipient strains 6015 and B157 do not make this protein. One-half of the 250 strain 6015 recipients tested, and one-third of the 250 strain B157 recipients tested, were found to make this $24 \mathrm{kDal}$ protein. To verify that the immunochemical procedure truly demonstrated the presence or absence of pRL6JI in the strains, DNA from eight of the B157 recipients was prepared and visualized on agarose gels. The three strains which made the $24 \mathrm{kDal}$ protein were the only ones to have acquired a plasmid of the size of pRL6JI (Fig. 1). (We do not know the frequency of cotransfer of pRL6JI with pRL13JI, because no suitable recipient strain is available for this experiment.) 
Table 2. Comparison of mutants and wild-type for Hup activity

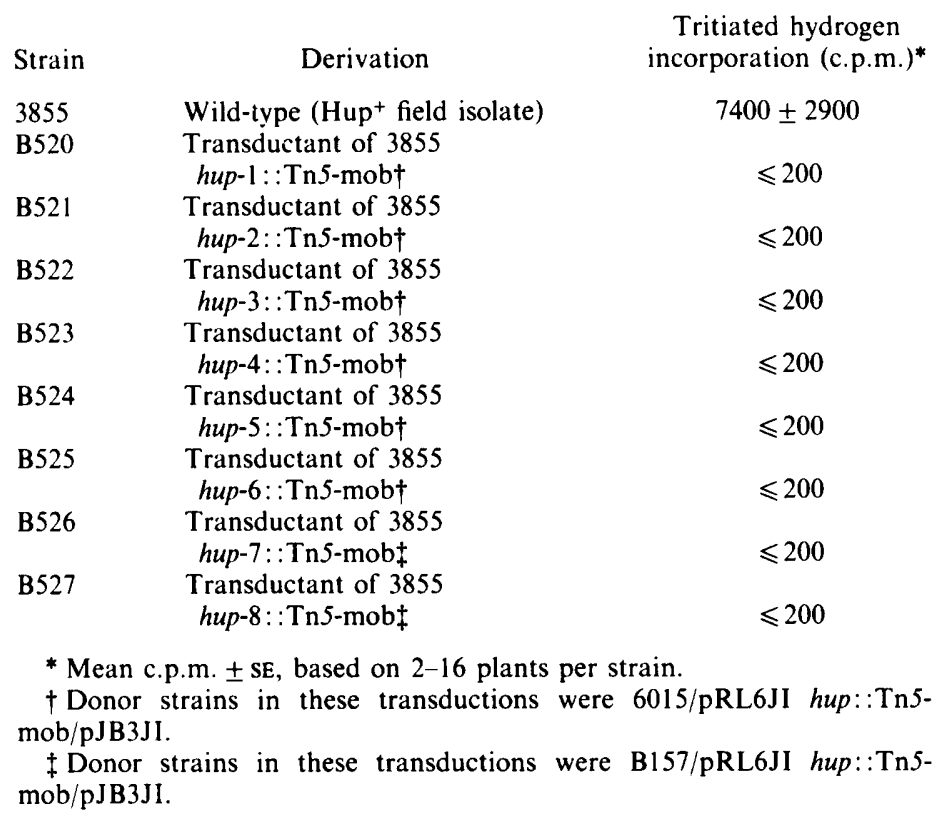

\section{Plant tests for tritium incorporation}

Each of the 212 strains containing pRL6JI was applied to the root system of two pea seedlings, and the resulting nodules were assayed for hydrogenase activity by tritium incorporation. (It is to be noted that plasmid pJB3JI interfered with normal nodule development, delaying the appearance of functional, nitrogen-fixing nodules by 4-11 d.) This delay was not dependent on the presence of $\mathrm{Tn} 5$-mob. Eight strains were found which were reproducibly deficient in this assay relative to the wild-type strain 3855 . Each of these strains was proficient in nitrogen fixation. In addition, we noted five strains which appeared to be deficient in nitrogen fixation, although they retained wild-type hydrogenase.

\section{Physical and genetic analysis of mutants}

Plasmids of all the hydrogenase-deficient mutants were visualized on agarose gels. Each mutant strain contained a plasmid of the same size as pRL6JI; therefore they did not harbour gross deletions.

The generalized transducing phage RL38 was propagated on each of the mutants, and the phage lysates were used to transduce the wild-type strain 3855 to kanamycin resistance. Kanamycin-resistant transductants were inoculated onto pea roots; all of them induced nodules which were deficient in hydrogenase activity (Table 2). Therefore, Tn5-mob is very closely linked to the hydrogenase genes. Eight of the transductants were also tested by patch crosses to see if the mobilization site was co-transduced with kanamycin resistance; in all cases it was.

Total DNA of each mutant strain was isolated, digested with the restriction enzyme BamHI (which cuts once within Tn5-mob), subjected to electrophoresis on an agarose gel, and probed for homology to Tn5. In seven out of eight cases, a unique pattern of hybridization was seen, suggesting that at least seven of the insertions were at different sites.

\section{Suppression of hydrogenase mutations}

Hydrogenase genes of Rhizobium japonicum were cloned into the cosmid vector pLAFR 1 by Cantrell et al. (1983), and shown to suppress some $R$. japonicum hydrogenase-deficient mutants for methylene blue reduction on Petri plates, for chemolithotrophic growth, and for hydrogen uptake in soybean nodules. We introduced this cosmid clone, pHU1, into each of our mutant 
Table 3. Complementation of Hup ${ }^{-}$strains of R. leguminosarum by heterologous DNA from $R$. japonicum

$\begin{array}{cc}\text { Strain } & \begin{array}{c}\text { Tritiated hydrogen } \\ \text { incorporation (c.p.m.) }\end{array} \\ 3855 / \text { pHUl } & 1050 \pm 280 \\ 3688 / \text { pHUl } & 5100 \\ \text { B520/pHU1 } & 2500 \pm 750 \\ \text { B521/pHU1 } & 2420 \pm 1120 \\ \text { B522/pHU1 } & 1070 \pm 400 \\ \text { B523/pHU1 } & 2350 \pm 530 \\ \text { B524/pHU1 } & 2550 \pm 1440 \\ \text { B525/pHU1 } & 2950 \pm 1510 \\ \text { B526/pHU1 } & 2020 \pm 900 \\ \text { B527/pHU1 } & 1430 \pm 350 \\ * \text { Mean c.p.m. } \pm \text { SE, based on } 8-10 \text { plants per strain. }\end{array}$

strains of $R$. leguminosarum by conjugation, using the mobilizing plasmid pRK2013. One transconjugant from each mutant was inoculated onto ten pea seedling root systems. Induced nodules were assayed by the tritium incorporation method. Whereas the cosmid clone pHU1 did not cause hydrogenase activity in nodules induced by strains of $R$. leguminosarum which lack hydrogenase ( 3688 or B157/pRL1JI), it did cause hydrogenase activity in each of the eight Hup ::Tn 5-mob mutants of $\mathrm{Hup}^{+}$strain 3855 (Table 3). Variability in tritium incorporation activity is believed to be due to the high degree of instability of the cosmid in the pea nodules, although we also find activity of strain 3855 very variable. The inability of cosmid pHU1 to make strain $3688 \mathrm{Hup}^{+}$confirms results obtained with $R$. japonicum which suggest that the cosmid clone pHUI does not contain all of the genes necessary to convert a Hup ${ }^{-}$field isolate into a hydrogenase producer. This result also demonstrates that genes from a slow-growing species, $R$. japonicum, can be expressed in a fast-growing species, $R$. leguminosarum. All bacteria isolated from nodules in this experiment retained kanamycin resistance; this suggests that the suppression of the mutant phenotype is not due to recombination.

\section{DISCUSSION}

Although found in both fast- and slow-growing rhizobia, hydrogenase systems seem to differ between the two groups in several ways. Hydrogenase activity is often found in isolates of slowgrowing rhizobia (such as cowpea and mungbean), less often in $R$. japonicum (soybean), and least often in fast-growing strains ( $R$. leguminosarum, $R$. trifolii, $R$. phaseoli, $R$. melilot $i$ ). In addition to this variation in frequency of occurrence, there is also a difference in the activity of the hydrogenases within root nodules, hydrogenases of slow growers being up to 1000 times more active than those of fast growers (Ruiz-Argüeso et al., 1979). The expression of hydrogenase in some slow growers can be induced in free-living bacteria under certain conditions of low oxygen and carbon supply (Maier et al., 1978), whereas expression of hydrogenase in fast growers has only been demonstrated in nodules.

Much work, both genetic and biochemical, has been devoted to the hydrogenase of $R$. japonicum (see review by Eisbrenner \& Evans, 1983). In contrast, very little is known about the hydrogenase from $R$. leguminosarum. Some hydrogenase genes from $R$. japonicum have been cloned (Cantrell et al., 1983) and they appear to span a region of at least $16 \mathrm{~kb}$. Although the cloned genes can suppress most Hup ${ }^{-}$mutations of $R$. japonicum, they cannot confer hydrogenase activity on field isolates of $R$. japonicum which lack the enzyme. This suggests that the hydrogenase genes might comprise a fairly large cluster.

We have isolated eight hydrogenase-deficient mutants of $R$. leguminosarum, which are due to insertion of transposon Tn5-mob. In the same mutagenesis we isolated five mutants which were deficient in nitrogen fixation $\left(\mathrm{Nod}^{+} \mathrm{Fix}^{-} \mathrm{Hup}^{+}\right)$. In Klebsiella pneumoniae the nitrogen fixation 
genes are thought to number at least 18. Assuming that similar numbers of nitrogen fixation genes are required in Rhizobium as in Klebsiella, we may expect the hup genes to be a fairly large set, since we obtained more Hup ${ }^{-}$mutants than Fix $^{-}$mutants. No mutants were recognized which gave reduced hydrogenase activity, but the extreme variability found in the tritium incorporation assay would have masked such a phenomenon.

All our Hup ${ }^{-}$mutants of $R$. leguminosarum were suppressible by cloned hup DNA from $R$. japonicum. This suggests close homology or functional compatibility between the proteins of the two species, which is surprising in view of the differences discussed above. The different values for tritium incorporation obtained with 3855 (Table 2) and 3855/pHU1 (Table 3) are not thought to be significant, since these experiments were done at different times with different batches of tritium.

DeJong et al. (1982) found that the R. leguminosarum $\mathrm{Hup}^{+}$plasmid pIJ 1008 (which is derived from pRL6JI) conferred improved symbiotic performance on strains which had received it. Although this plasmid contains many genes which could affect symbiotic performance (Brewin et al., 1983), one attractive possibility was that this benefit might be due to hydrogenase. In order to assess the importance of hydrogenase we undertook this study, in which we isolated eight Hup $^{-}$mutants. Plants inoculated with these mutants will be compared to those inoculated with their wild-type parent, in order to assess the role of hydrogenase in the plant/bacterium symbiosis.

This work has been supported financially by the British Technology Group and intellectually by Drs J. A. Downie and A. W. B. Johnston. In addition Professor D. A. Hopwood, Dr J. P. W. Young and Mrs A. Williams gave their help in the production of the manuscript.

\section{REFERENCES}

BERINGER, J. E. (1974). R factor transfer in Rhizobium leguminosarum. Journal of General Microbiolog! 84, 188198.

Beringer, J. F., Hoggan, S. A. \& Johnston, A. W. B. (1978). Linkage mapping in Rhizohium leguminosarum by means of $\mathrm{R}$ plasmid-mediated recombination. Journal of General Microbiology 104, 201-207.

Beynon, J. L., Beringer, J. F. \& Johnston, A. W. B. (1980). Plasmids and host range in Rhizobium leguminosarum and Rhizohium phaseoli. Journal of General Microbiology 120, $421-429$.

Brewin, N. J., DeJong, T. M., Phillip, D. A. \& Johnston, A. W. B. (1980). Co-transfer of determinants of hydrogenase activity and nodulation ability in Rhizohium leguminosarum. Nature, London 288, 7779.

Brewin, N. J., WoOd, E. A., Johnston, A. W. B., DibB, N. \& Hombrecher, G. (1982). Recombinant nodulation plasmids in Rhizohium leguminosarum. Journal of General Microhiology 128, 1817-1827.

Brewin, N. J., DibB, N. J. \& Hombrecher, G. (1983). Natural variation in Rhizobium plasmids. In Molecular Genetics of the Bacteria. Plant Interaction, pp. 113 121. Edited by A. Puhler. Berlin \& Heidelberg: Springer-Verlag.

Buchanan-Wollaston, V. (1979). Generalized transduction in Rhizohium leguminosarum. Journal of General Microbiology 112, 135-142.

Buchanan-Wollaston, A. V., Beringer, J. E., Brewin, N. J., Hirsch, P. R. \& Johnston, A. W. B. (1980). Isolation of symbiotically defective mutants of Rhizobium leguminosarum by insertion of the transposon TnS into a transmissible plasmid. Molecular and General Genetics 178, 185-190.
Cantrell, M. A., Haugland, R. A. \& Evans, H. J. (1983). Construction of a Rhizohium japonicum gene bank and use in the isolation of a hydrogen uptake gene. Procesdings of the National Academy of Sciences of the United States of America 80, 181-185.

DeJong, T. M., Brewin, N. J., Johnston, A. W. B. \& Phillips, D. A. (1982). Improvement of symbiotic properties in Rhizohium leguminosarum by plasmid transfer. Journal of General Microbiology 128, 1829 18.38.

Dibb, N. J., Downie, J. A. \& Brewin, N. J. (1984). The identification of a rhizosphere protein encoded by the symbiotic plasmid of Rhizohium leguminosarum. Journal of Bacteriolog! 158, 621 627.

Ditta, G., Stanfield, S., Corbin, D. \& Helinski, D. R. (1980). Broad host range DNA cloning system for Gram-negative bacteria; construction of a gene bank of Rhizohium meliloti. Proceedings of the National Academy of Sciences of the United States of America 77, 73477391.

Downie, J. A., MA, Q.-S., Knight, C. D., HomRRECHER, G. \& JOHNSTON, A. W. B. (1983). Cloning of the symbiotic region of Rhizobium leguminosarum: the nodulation genes are between the nitrogenase genes and a nifA-like gene. EMBO Journal 2, $947-$ 952.

Eisbreniner, G. \& Evans, H. J. (1983). Aspects of hydrogenase metabolism in nitrogen fixing legumes and other plant microbe interactions. Annual Review of Plant Physiology 34, 105-136.

Hirsch, P. R., VAN Montagu, M., Johnston, A. W. B., BrewiN, N. J. \& Schell, J. (1980). Physical identification of bacteriocinogenic nodulation and other plasmids in strains of Rhizobium 
leguminosarum. Journal of General Microbiology 120 , 40) 412 .

Johnston, A. W. B., Beynon, J., Buchanan-WollasTON, A. V., Setchell, S. M., Hirsch, P. R. \& BERINGER, J. E. (1978). High frequency transfer of nodulating ability between strains and species of Rhizohium. Nature, London 276, 635-636.

Lepo, J. E., Hickok, R. E., Cantrell, M. A., Russell, S. A. \& Evans, H. J. (1981). Revertible hydrogen uptake-deficient mutants of Rhizobium japonicum. Journal of Bacteriology 146, 614-620.

MAIER, R. J. (1981). Rhizohium japonicum: mutant strains unable to grow chemoautotrophically with $\mathrm{H}_{2}$. Journal of Bacteriology 145, 533-540.

Maier, R. J., Campbell, N. E. R., Hanus, F. J.,
Simpson, F. B., Russell, S. A. \& Evans, H. J. (1978). Expression of hydrogenase activity in free-living Rhizobium japonicum. Proceedings of the National Academy of Sciences of the United States of America 75, $3258 \cdots 3262$.

Ruiz-Argüeso, T., Maier, R. J. \& Evans, H. J. (1979). Hydrogen evolution from alfalfa and clover nodules and hydrogen uptake by free-living Rhizobium meliloti. Applied and Environmental Microbiology 37, 582-587.

Simon, R.. Priefer, U. \& Pühler, A. (1983). Vector plasmids for in tivo and in ritro manipulations of Gram-negative bacteria. In Molecular Genetics of the Bacteria Plant Interaction, pp. 98-106. Edited by A. Pühler. Berlin \& Heidelberg: Springer-Verlag. 